\title{
Klinik Tıp Kütüphaneciliği
}

\author{
Clinical Medical Librarianship
}

\section{Nazlı ALKAN ${ }^{*}$}

\section{Değerli Tıp Kütüphanecimiz Sevinç Uşen'in Anısına}

\section{Öz}

Esasen tıp ve sağlık bilimleri literatürünü hasta yatağı başına ulaştırmayı öngören Klinik Tıp Kütüphaneciliği (KTK) uygulamaları, tıp ve sağlığa ilişkin bilgi erişim sorunlarına getirilen en güvenilir çözümlerden biri olmuştur. Günümüzde hekim ve sağlık professyonellerinin hastalığın tanı ve tedavisiyle veya araştırma alanlarıyla ilgili kararlarının yalnızca literatürde bulunan anlamlı bilgiyle değil, literatürde bulunan güvenilir kanıtlarla da desteklenmesi gerekmektedir. Dolayısıyla KTK, Kanıta Dayalı Tıp (KDT) uygulamasını ve bu uygulamanın ortaya çıkarttığı KDT kütüphaneciliğinin ilkelerini de işin içine katmaktadır. KTK genellikle, tıp ve sağlık bilimleri kütüphanecisinin hasta vizitelerine, vaka sunumu toplantılarına, klinik, eğitim veya bölüm konferanslarına katılmasıyla gerçekleştirilmekte, hekim ve sağlık profesyonellerinin karar verme, araştırma ve eğitim süreçlerini desteklemek üzere onlara gereksinme duydukları yer ve zamanda kaliteli, süzülmüş bilgi ve kanıtları sağlamaya odaklanmaktadır. Bu çalışmada, özellikle ülkemiz tıp ve sağlık bilimleri kütüphanecilerinin KTK konusunda aydınlatılması amacıyla hizmet, tanımları, program ve yaklaşımları, avantaj ve dezavantajları açısından ele alınmış, ayrıca KTK'nin gelecekte Türkiye'de uygulanabilirliği tartışılmıştır. KTK'nin Türkiye'de uygulanabilirliği, KTK ve KDT kütüphaneciliği alanlarında sunulan sürekli meslekî eğitim programlarından yararlanarak yetişecek olan nitelikli tıp ve sağlık bilimleri kütüphanecilerinin varlığına bağlıdır. 
Kütüphanecilerimiz KTK hizmetlerini KDT kütüphaneciliği esasları doğrultusunda etkin bir şekilde uygulayabildikleri zaman, ülkemizde hizmetlerin tıp ve sağlık alanları ve kütüphanecilik mesleği üzerindeki olumlu etkileri görülebilecektir.

Anahtar sözcükler: Kanıta dayalı tıp kütüphaneciliği, Kanıta dayalı tıp, Tıp enformasyonu, Kütüphanecilik, Türkiye

\section{Abstract}

Clinical Medical Librarianship (CML) practices which principally aim to carry the medical and health sciences literature to patient bedside have been one of the most reliable solutions to information retrieval problems in regard to medicine and health. Today not only the relevant information, but also the reliable evidence found in the literature is required by doctors and health professionals to support their diagnosis, therapy or research decisions. Consequently CML also involves the principles of Evidence-Based Medical Librarianship (EBML) emerged from Evidence-Based Medicine (EBM) practice. $C M L$ is generally achieved through the medical and health sciences librarian's participation in patient rounds, morning reports or clinical, educational, departmental conferences and it focuses on providing the quality filtered information and evidence to doctors and health professionals, when and where they need them, in order to support their decision making, research and educational processes. This study aims to enlighten the Turkish medical and health sciences librarians particularly, about CML. To achieve this aim, definitions, programs and approaches, advantages and disadvantages of the services are introduced, besides the future applicability of the services in Turkey is discussed. The application of CML in Turkey depends on the existence of qualified medical and health sciences librarians who will be trained through continuous professional education programs on $C M L$ and EBML. When these librarians apply effective CML services in the line of EBML in Turkey it will be possible to see the positive effects on medical and health areas and on the profession of librarianship.

Keywords: Evidence based librarianship, Evidence based medicine, Medical informatics, Librarianship, Turkey 


\section{Giriş}

Günümüzde tıp ve sağlığa ilişkin bilgi patlaması inanılması güç yoğunluktadır. Özellikle son 10-15 yıl içinde tıp ve sağlığa yönelik araştırma alanları ve klinik uzmanlık dallarında görülen önemli gelişmelerin etkisiyle artan literatürün hacmi, normal koşullarda meşgul uzman hekimlerin ve sağlık profesyonellerinin alanlarındaki güncel ve anlamlı bilgiye erişmelerini zorlaştırmaktadır. Bu koşullarda, araştırma, uygulama ve eğitim ile literatür arasındaki boşluğu kapatmada ve bilgi erişim sorununa çözüm getirmede tıp ve sağlık bilimleri kütüphanecileri hekim ve sağlık profesyonellerinin en önemli yardımcıları olmakta, onlara, büyük literatür yığını arasından seçilen en gereksinim karşılayıcı ve nitelikli bilgiye en kısa zamanda erişim olanaklarını sunmaktadırlar.

Özellikle klinik tıp literatürünü hasta yatağı başına getirmeyi öngören Klinik Tıp Kütüphaneciliği (KTK), yaklaşık 40 yıllık geçmişiyle, tıbbî bilgi erişim sorununa getirilen en güvenilir çözümlerden biri olmuştur. İlk KTK programı 1967'de Washington Hastane Merkezi (Washington Hospital Center)'nde başlatılmıştır (Cimpl, 1985, s. 24). 1970'lerin başlarında Londra'da Guys Hastanesi (Guys Hospital)'nde KTK uygulamasına geçildiği, ancak uygulamanın sürdürülemediği bilinmektedir (Sargeant ve Harrison, 2004, s. 174). Hatta 1950'lerin ortalarında Goodall (1954, s. 19) tıp kütüphanecilerinin klinisyenleri literatür belirleme gibi sıkıcı işlerden kurtarmayı hedeflediklerini ve bunu bir sorumluluk olarak gördüklerini ifade ederek, sonradan ortaya çıkacak olan KTK'nin öncü fikirlerini ileri sürmüştür. Bu aşamalara rağmen, KTK kavramının ilk kez 1971'de ABD'de Gertrude Lamb tarafından tanımlandığı kabul edilmektedir. Getirdiği tanımlamalar doğrultusunda Lamb (1974, s. 521), Kansas City'deki Missouri Üniversitesi (University of Missouri at Kansas City-UMKC) Tıp Fakültesi Hastanesi'nde kütüphanecilerin hasta vizitelerine katılmasıyla KTK'nin ilk ve asıl programını gerçekleştirmiştir. KTK'nin en geliştiği yer esas vatanı ABD olmakla birlikte, bugün İngiltere, Kanada, Avustralya, Hollanda gibi ülkelerde de başarılı uygulama örneklerini görmek mümkündür. Günümüzde KTK, başta klinisyen hekimlerin hastalığın tanı ve tedavisiyle ilgili kararlarının yalnızca literatürde bulunan bilgiyle değil, literatürde bulunan 
güvenilir kanıtlarla da desteklenmesini gerektirmekte, dolayısıyla Kanıta Dayalı Tıp (KDT) uygulamasını ve bu uygulama doğrultusunda gelişen KDT kütüphaneciliğinin esaslarını işin içine katmaktadır. KTK, KDT gereğince gerçekleştirilmedikçe sınırlı bir etkiye sahip olmaktadır.

Çalışmamızda, KTK'nin tanımları, program ve yaklaşımları, avantaj ve dezavantajları, seçilmiş KTK uygulaması örnekleri sunularak, özellikle ülkemizdeki tıp ve sağlık bilimleri kütüphanecilerinin aydınlatılması amaçlanmış, bu tıp ve sağlık bilimleri kütüphaneciliği dalının Türkiye'de uygulanabilirliği tartışılmıştır. Söz konusu amaç doğrultusunda, konunun geniş literatürü arasından seçilen literatür örneklerine dayanılarak gerçekleştirilen, temel bilgileri seçilmiş uygulama örnekleriyle birlikte ele alan bu giriş çalışmasının, gelecek çalışmalara ve ülkemizdeki başlangıç uygulamalarına ışık tutacağı kanısındayız.

\section{Tanımlar}

Lamb (1974, s. 521)'e göre KTK, klinik uygulamalarıyla tıp literatürünü birleştirmeyi, klinik sorunlarına literatürden seçilmiş örneklerle çözüm getirmeyi amaçlayan bir kütüphanecilik dalıdır. Lamb, Amerikan Tıp Kütüphanecileri Derneği (Medical Library Association-MLA, 2007) sitesinde yer alan, kendisiyle 1985'de yapılan bir röportajın metninde KTK uygulamasını şöyle tanımlamıştır: “... karar verebilmek için, enformasyonun en çok gereksinme duyulduğu noktaya getirildiği bir enformasyon sistemidir. Hizmet en etkin şekilde bir tıp kütüphanecisi tarafından verilebilir, çünkü onun kütüphaneciliğe özgü iki benzersiz becerisi vardır; [bunlar] bir soruyu nasıl soracağını ve literatüre nasıl erişeceğini bilmesidir". Söz konusu röportaj metnine (MLA, 2007) göre Lamb KTK'nin "...bir öğretim hastanesi ortamında ifade edilebilen ve edilemeyen enformasyon gereksinmelerini karşılayabilmenin bir yolu...” olduğunu düşünmüş, “...kütüphanecinin bir hastanede belli bir soruya yanıt alma gereksinmesi duyan klinisyenler için enformasyon süzücüsü rolünü oynaması..." gerektiğini savunmuştur. Winning ve Beverley (2003, s. 11)'in Veenstra ve Gluck (1992)'un tanımını esas alarak getirdikleri tanıma göre ise KTK, kliniğe yönelik karar vermeyi desteklemek üzere 
hekim ve diğer sağlık profesyonellerine kalite yönünden süzülmüş, hastalık vakasına özgü bilgiyi sağlamayı amaçlayan bir kütüphanecilik uygulamasıdır. Bu uygulama konuya yönelik bilgiyi sunmadan çok, kullanıcıya yönelik bilgiyi sunma temel anlayışına odaklanmalıdır (Cimpl, 1985, s. 23). Bu hizmet kapsamında klinik kütüphanecileri ekiplerde aktif bir rol üstlenerek ekip üyelerine hasta merkezli araştırma bulgularını sunarlar, böylelikle katma değerli hizmetler sağlamayı benimsemiş olurlar (Buchanan, 2004).

Bugün KTK, kliniğe ilişkin bir soruya yanıt vermek üzere anlamlı kimliklerden oluşan bir literatür listesini, kimliklere ait özet veya tam metinleri sağlamanın ötesinde bir hizmet anlayışına odaklanma eğilimindedir. Öyle uygulamalar vardır ki kütüphaneciler vakaya ilişkin anlamlı literatürü en kısa zamanda belirleyip bulduktan sonra, en gereksinme giderici anlamlı bilgiyi metin içinden bulup çıkarmak üzere onu okuma ve analiz etme eylemine girişirler ve bulgularını özetleyerek ilgili ekip üyelerine vizite esnasında veya hasta konferanslarında sunarlar (Davidoff ve Florance, 2000, s. 997; Alkan, 2002a, s. 82). Böylelikle hastanın hastalığına özgü tanıtedavi yöntemleriyle ilgili kaliteli, süzülmüş bilgiyle hasta sağlığına katkıda bulunulabilir. Son yıllarda daha da öteye geçilmiş, hekimlerin hastalığın tanı ve tedavisiyle ilgili kararlarının, literatürde bulunan güvenilir ve güncel kanıtlara dayandırılma zorunluluğu gereğince ortaya çıkan KDT ile ona bağlı olarak gelişen KDT kütüphaneciliğinin ilke, uygulama, yöntem ve teknikleri KTK hizmetleri aracılığı ile kliniklere taşınmıştır. Artık KTK, yalnızca hastaya özgü problem çözücü, kaliteli, anlamlı, süzülmüş bilgiyi hekimlere ve diğer sağlık personeline hızla ulaştırmakla kalmamakta, bu özellikleri taşıyan literatürün aynı zamanda güçlü kanıtlar içermesine de önem vermektedir. KDT modelinin temel aşamalarının ikincisi olan "soruları yanıtlamak ve en iyi kanıtları bulmak üzere literatür taramaları yapmak" (Alkan, 2005, s. 44), genelde tıp ve sağlık bilimleri kütüphanecilerini, özelde klinik kütüphanecilerini zorunlu olarak KDT uygulamaları içerisine çekmekte ve "Cochrane Library" gibi kanıta dayalı veri tabanlarından literatür taramaları yapmalarını gerektirmektedir. Alkan (2005, s. 61)'ın belirttiği gibi, Scherrer ve Dorsch (1999, s. 323)'a göre 1970'lerin ortalarında geliştirilmeye başlanan KTK 
uygulamaları kütüphanecilerin KDT sürecine katılmalarının başlangıcı olarak değerlendirilir. Bazı KTK uygulamalarında kütüphaneci kanıt içeren literatüre erişmekle kalmayıp, eriştiği literature değer biçip onu özetleyip raporlaştırarak hekimlere ve diğerlerine sunmakta, böylece KDT modelinin üçüncü temel aşaması olan "karar vermeyi desteklemek üzere erişilen literatüre değer biçme" (Alkan, 2005, s. 44) nin yerine getirilmesine katkıda bulunmaktadır. Literatüre değer biçme, belirlenmiş sıkı kurallara uyularak ve makalenin uyguladığı araştırma tasarımı göz önüne alınarak yapılmaktadır. Her araştırma tasarımının sunabildiği kanıt düzeyi farklıdır. Kütüphaneci, kurallar doğrultusunda, araştırma tasarımını da dikkate alarak nesnel ve eleştirel yaklaşımlarla literatürün kalitesine ve sunduğu kanıtlara değer biçebilmektedir (Booth ve Brice, 2004, s. 105). Alkan (2005, s. 61)'ın Scherrer ve Dorsch (1999, ss. 323-324)'un görüşlerine dayanarak belirttiğine göre, KDT "...kütüphanecinin, kanıt içeren klinik tıp literatürünü yalnızca en doğru biçimde elde etmesini değil, eriştiği literatürü süzerek seçmesini, seçtiklerine kalite ve kanıt sunma düzeyi açısından değer biçmesini ve sentezlemesini gerektiren, ona enformasyon sürecinin tamamına katılma ve katma değerli hizmetler sunma fırsatı veren bir süreçtir". KDT, KTK'nin geliştirilmesi için yeni olanaklar getirirken, KTK de KDT uygulamalarının geliştirilmesinde önemli bir rol oynamaktadır. KTK bugün KDT sürecinin kütüphaneciye yüklediği sorumlulukları da içererek sürdürüldüğüne göre, ona çağdaş ve oldukça geniş kapsamlı bir tanım getirme zorunluluğu vardır. Bu çerçevede şu tanım geçerli olabilir: KTK, genellikle hastane kliniklerinde hekim ve sağlık profesyonellerinin hasta sağlığına yönelik kararlarını, eğitim ve araştırma etkinliklerini desteklemek üzere, KDT uygulamalarına karşı duyarlı bir yaklaşımla, onlara gereksinme duydukları, vakaya özgü, problem çözücü, anlamlı, kaliteli, süzülmüş, güçlü kanıtlar içeren, değer biçilmiş ve sentezlenmiş bilgiyi, mümkün olan en kısa sürede ve en az maliyetle iletmeyi amaçlayan, katma değerli hizmetler sunmaya odaklanan bir tıp ve sağlık bilimleri danışma kütüphaneciliği dalıdır. 


\section{Klinik Tıp Kütüphaneciliği Programları ve Uygulama Örnekleri}

Hastaya yönelik bilgiyi, literatür taraması yaparak hızla sağlamak üzere, temelde kamuya, özel sektöre veya akademik tıp ve sağlık kuruluşlarına bağlı hastanelerde ve çeşitli tıbbî araştırma ortamlarında, varolan koşul ve gereksinmeler doğrultusunda farklı KTK programları uygulanmaktadır. Literatürde kimi zaman uygulama, yaklaşım, model, teknik veya yöntem adıyla geçen bu programların geliştirilerek, değiştirilerek, tek başlarına ya da birlikte uygulanabildiği görülmektedir. Aşağıda çeşitli yollarla gerçekleştirilen KTK programları örnekleri, mümkün olduğunca ait oldukları grup içinde ele alınarak sunulmuştur. Programları uygulayan kurum örnekleri arasında KDT kütüphaneciliğini uygulayanlar da vardır.

1. Hasta Vizitelerine Katılma:

Hasta vizitesi, temelde hekimlerin içinde yer aldığı bir sağlık bakımı ekibinin, yatan hastaların durumlarını değerlendirmek üzere hastane koğuş veya kliniklerine yaptıkları ziyareti ifade eder. KTK'nin önde gelen amacı, kütüphanecileri klinik ekiplerine katmak ve hasta vizitelerinde yer almalarını sağlamaktır. Danışma kütüphanecilerinin kütüphaneden ayrılarak kliniklere yöneltilmesi ve bilgi sağlamak üzere vizitelerde ekiptekilere eşlik etmesine dayanan hizmet, 1971'de ABD'de başlatılmış, 1970'lerin ortalarından itibaren, özellikle bu ülkede, giderek geliştirilerek uygulanmış ve yaygınlaşmıştır (Cimpl, 1985, s. 21).

Alkan (2002a, s. 81; 2002b, s. 28; 2005, s. 61)'ın bazı çalışmalarında, Demas ve Ludwig (1991, s. 18)'in görüşlerine dayanarak KTK hakkında verdiği bilgi, kütüphanecinin sağlık bakımı ekibi içindeki rolüne odaklanırken, bu kütüphanecilik uygulamasının hasta vizitelerine katılım bağlamındaki tanımını ortaya çıkarmaktadır: KTK, kütüphanecinin hekim, hemşire diyetisyen, eczacı, sosyal hizmet uzmanı, psikolog ve tıp öğrencilerinden vb. oluşan sağlık bakımı ekibinin bir üyesi olarak, hasta vizitelerine katılması, hastanın durumunun yatak başında değerlendirilmesi sırasında ekiptekilerin sorularını saptaması, soruları yanıtlayacak literatürü bulmak üzere kütüphanede tarama yapması, eriştiği kimlikleri, bunlara ait özetleri veya tam metinleri, genellikle en çok 24 
saat içinde iletmesi esasına dayanan bir uygulamadır. $\mathrm{Bu}$ uygulamanın etkinliği, çoğunlukla kurumun tıp ve sağlık bilimleri kütüphanesinin kendi koşullarına göre sağlayabildiği kütüphaneci sayısına ve kütüphanecilerin kaliteli bilgiye eriştirebilme yeteneklerine göre belirlenir. Kütüphaneciler genellikle kütüphanedeki işlerine ek olarak KTK hizmetini de verirler. Son yıllarda bazı kütüphaneler bu hizmet için ayrı klinik kütüphanecisi kadroları sağlayabilmişlerdir.

Cimpl (1985, ss. 22-23), 1971-1981 arasında vizitelere katılım esasına dayanan ABD programlarından örnekler vererek bunları kısaca tanımlamış, hizmetin kaç kütüphaneciyle, haftada kaç kez, hangi hastane bölümlerine, ne şekilde sunulduğu hakkında bilgi vermiştir. Yazarın yaptığı genel değerlendirmeye göre, kütüphaneciler haftada ortalama üç saat vizite katılımına, dört saat tarama yapmaya ayırmışlar, bibliyografyalar ve ilgili makalelerin dağıtımı için de belli bir zaman harcamışlardır. Diğer taraftan konuyla ilgili zengin literatür, ki genellikle klinik kütüphanecilerinin kendi uygulamalarına yöneliktir, vizitelere kütüphaneci katılımına dayanan uygulamalar hakkında bilgi vermektedir. Özellikle Winning ve Beverley (2003) ile Wagner ve Byrd (2004)'ün dizgesel/sistematik derleme tarzındaki makaleleri kütüphanecinin vizitelere katılımına dayalı hizmet programlarını incelemek için yararlıdır. Winning ve Beverley (2003, ss. 14-15), 1986-2001 arasında yayımlanan konuyla ilgili seçilmiş literatürü ve hizmet değerlendirmesi çalışmalarını, Wagner ve Byrd (2004, ss. 17, 2229) ise 1974-2001 arasında yayımlanan seçilmiş değerlendirme çalışmalarını ele alarak kütüphanecilerin vizitelere katılımıyla gerçekleştirilen programlar da dahil olmak üzere, uygulanan çeşitli programlar hakkındaki bilimsel nitelikli literatüre yönlendirmekte, bilgi edinimini kolaylaştırmaktadır. Wagner ve Byrd (2004, ss. 2229)'in kapsama aldıkları literatürü kronolojik olarak sıralayarak hazırladıkları tablo, vizitelere kütüphaneci katılımının ABD, İngiltere ve diğer ülkelerin hangi kurumlarında gerçekleştirildiği, kaç kütüphanecinin ne sıklıkta vizitelere katıldığı gibi bilgilerin kolayca incelenmesine olanak vermekte, aynı zamanda hizmetleri değerlendirme çalışmalarının amaç ve bulgularını sunmaktadır. 
Temelde kütüphanecinin vizitelere katılımıyla gerçekleştirilen programları temsilen iki gelişmiş ABD örneğine değinmekte yarar vardır:

\section{Kansas City'deki Missouri Üniversitesi Tıp Fakültesi Hastanesinde KTK Uygulaması:}

Tıp danışma kütüphanecilerinin vizitelere katılmasıyla 1971'de Amerikan Ulusal Tıp Kütüphanesi (National Library of MedicineNLM)'nden alınan para desteği ile UMKC Tıp Fakültesi Hastanesi'nde başlatılan program, vizitelere dayalı programların ilkidir. UMKC adıyla tanınan program, KTK hizmetini ilk tanımlayan ve uygulayan Lamb'in eseridir. Başlangıç yıllarında üç klinik kütüphanecisinin her biri üç ayrı doçent ekibinin birer üyesi olmuşlardır. Öncelikle, Tıp Fakültesinin akademik plânı gereğince oluşturulan çok üyeli doçent ekiplerine değinmek gerekir. Altı yıllık tıp eğitiminin son dört yılı klinik tıp hizmetine ayrılmıştır; öğrenciler bu süre içinde bir doçent ekibinde her yıl 12 hafta boyunca vizitelere katılmak, çeşitli tıp uzmanlık dallarında rotasyon yapmak, doçentlerin gözetiminde hastalara karşı sorumluluk almak zorundadırlar. Bir doçent ekibi, üst düzey bir doçentin başkanlığında, diğer doçentler, intörn, hemşire ve eczacılar, yardımcı personel ve bir grup tıp öğrencisinden oluşan kalabalık bir gruptur. Ekipler, bir klinik birimine ve çok sayıda poliklinik hastasına hizmet vermek üzere tasarlanmıştır. Üç kütüphaneciden her biri, üç doçent ekibinden birinin günlük, öğretim temelli vizitelerine düzenli olarak girmiş, hastayı görerek, tartışmalara katılarak, hasta dosyasını inceleyerek ekiptekilerin bilgi gereksinmelerini belirlemiş ve karşılamıştır. Her bir kütüphaneci bağlı olduğu ekip için ayrı bir bilgi iletim tekniği uygulamıştır. Bu üç teknikten biri, her sabah kütüphanecinin vizitelere katılmasıyla gerçekleştirilen LATCH (Literature ATtached to the CHart), yani hasta dosyasına iliştirilmiş literatür tekniğidir. Aşağıda daha ayrıntılı olarak değinilen LATCH, kütüphanecinin bir hastayla ilgili bilgi gereksinmesini karşılamak üzere yaptığı taramanın sonuçlarını o hastanın dosyasına iliştirmesi esasına dayanır. İkinci ekibe, vizitelerde tartışılan hastalık problemleriyle ilgili dikkatle seçilmiş güncel kilit makalelerin ve hastalığın tarihçesine ilişkin bir makalenin özetlerini içeren "Güncel Referanslar" (Current References) başlıklı haftalık bir yayın 
dağıtımıştır. $\mathrm{Bu}$, her hafta bilgi sunmaya odaklanan bir iletim tekniğidir. Üçüncü ekipte ise, kullanıcı gereksinmelerini önceden tahmine dayalı olarak üretilen bir dizim sisteminden yararlanılmıştır. "En Son Bahisler" (Latest Topics) adıyla oluşturulan bu sistem kanalıyla, önceden istek üzerine hazırlanan taramaların sonuçlarından ve belgelerden yararlanmak olanaklı kılınmıştır. Tekrarlanan istekleri karşılamak üzere kullanılan bu bilgi iletim tekniği bilginin güncelleştirilerek sunulmasını gerektirmiştir. UMKC Sağlık Bilimleri Kütüphanesi önderliğinde geliştirilen bu teknikler, sonradan değerlendirilmek üzere uygulanmıştır. Her bir kütüphaneci tarafından ayda ortalama 80-100 MEDLINE taraması yapılmış, ulaşılan makaleler analizlenmiş, sonuçta sadece dikkatle seçilmiş olanlar kullanıcıya en çok 24 saat içinde iletilmiştir (Algermissen, 1974 , ss. 354-355).

UMKC Sağlık Bilimleri Kütüphanesinin doçent ekiplerine bilgi desteği sağlayan klinik kütüphanecileri bugün hâlâ faaliyettedir. Kütüphanenin web sitesindeki (University of Missouri at Kansas City-UMKC. Health Sciences Library, 2007) bilgiye göre, KTK programının temel amacı İç Hastalıkları Birimleri rotasyonlarında karşılaşılan hasta bakımı hususlarının öğrenciler tarafından daha iyi anlaşılmasını olanaklı kılmak üzere onlara eğitimi destekleyici bilgiyi sunmak ve hekimlerle diğer ekip üyelerine hastaya yönelik en iyi sağlık bakımını verebilmeleri için ilgili bilgiyi sağlamaktır. Bugün kütüphaneciler iki ay süreyle İç Hastalıkları Birimlerindeki doçent ekipleriyle günlük vizitelere katılmakta, öğrenmeye yönelik klinik tartışmalarını dinlemekte, ekip üyelerinin sorularına ilişkin taramaları yaparak eriştiklerini gün bitmeden ilgilisine iletmektedirler. Makaleler diğer ekip üyelerinin de okuması için birimlerde bırakılmakta ve üzerlerinde tartışılabilmektedir. Ayrıca, ekip üyeleri bir bilgi aradıklarında kütüphaneci onlara bireysel danışmanlık hizmeti vermekte, tarama stratejisi oluşturmalarında ve kaynak sağlamalarında yardımcı olmaktadır. Biyotıp veri tabanlarına, İnternet'e, basılı kaynaklara erişimi; tarama ve değerlendirmeyi; KDT ve tıbbî enformatik kavramlarını öğretmek için kütüphaneci tarafından öğrenci ve öğretim üyelerine formal eğitim de verilmektedir. Kütüphaneciler ekip üyelerine isabetli kararlar verebilmeleri ve öğrenme deneyimlerini en üst düzeye 
çıkarabilmeleri için özelleştirilmiş hizmetler vermekte, özel klinik konularında hazırladıkları özetleri vizitelerde sunmaktadırlar. Sonuç olarak UMKC programı, vizitelere dayalı KTK uygulamalarının ilki olarak 37 yıldır sürdürülmekte, başarılarıyla yeni girişimlere örnek olmaktadır.

\section{Vanderbilt Üniversitesi Tıp Merkezi Hastanesinde KTK Uygulaması:}

Tennessee Nashville'deki Vanderbilt Üniversitesi Tıp Merkezi (Vanderbilt University Medical Center-VUMC)'ndeki Eskind Biyotıp Kütüphanesi'nin 1996'da başlattığı KTK programı da dünyanın en gelişmiş örneklerinden biridir. Temelde kütüphanecilerin günlük yatak başı vizitelerine katılımıyla gerçekleştirilen, Vanderbilt, VUMC veya Kliniğe Yönelik Enformatik Danışmanlığı Hizmeti (Clinical Informatics Consult Service-CICS) adlarıyla tanınan ve ileri düzeyde yaklaşımlarıyla yürütülen bu program, kendi kurumlarında hizmeti geliştirmek isteyenleri etkilemekte ve yönlendirmektedir. Program, kütüphanecilerin gerçek anlamda klinik ekipleriyle bütünleşmesini öngörürken, yüksek kalitede bir sağlık bakımının sağlanabilmesi için onların eğitilmesine de önem vermektedir. Kütüphanecilerin klinik bilgilerini, vizitelerde iyi iletişim kurma, verimli taramalar yapma, erişilen literatürü yorumlama vb. becerilerini geliştirmeleri için verilen eğitim, programın kilometre taşlarından biridir. Eskind Biyotıp Kütüphanesinin hasta bakımı ve araştırmaya yönelik doğru ve özel bir hizmeti gereksinme duyulduğu anda vermek, zamanında gerçekleştirilen girişimlerle başta hekimlerin bilgisini artırmak, kütüphanecinin bilgi erişimdeki rolünü güçlendirmek gibi amaçlarına ulaşmasında hasta viziteleri ideal ortamlar olmuşlardır (Giuse ve diğerleri, 1998, s. 413).

Geleneksel KTK genellikle kliniğe yönelik bir soruya yanıt veren en anlamlı makale kimliklerinin bir listesini ve/veya bir anlamlı makaleler destesini sunmaya odaklanır. Oysa ekiptekilere sunulan son ürün bunlardan ibaret olmamalıdır. Bu tip listeler ve/veya makaleler kütüphanecinin uzmanlaşmış bilgi ve çabasını gerçek anlamda ortaya çıkaramaz (Giuse ve diğerleri, 1998, s. 414). Kütüphaneciler, vizitelere katılan ekip üyelerinin isteklerini en iyi şekilde karşılayabilmek için, karmaşık taramalarla erişilen hastaya 
özel bilgiyi analizleyip yorumlayan, süzen ve özetleyen meslekten kişiler olarak hizmet vermeli ve bu doğrultuda yetiştirilmelidir. Böyle bir bakış açısıyla, kütüphanecilerin tıp literatürünü bulma ve değerlendirmede kendilerine özgü bir uzmanlıkları olması gerektiği görüşünü benimseyen Eskind Biyotıp Kütüphanesi, KTK'nin geleneksel tabanını bir adım öteye taşıyarak KDT uygulamasına dönük bir anlayışla geliştirilmiş CICS programını devreye sokmuştur. CICS'in arkasındaki temel görüş, tıbbî uzmanlık alanlarında, özellikle kanıta yönelik olarak, bilgi ve becerileri sürekli geliştirilen kütüphanecilerin, ekiplerin gerçekten vazgeçilmez üyeleri olduklarıdır (Giuse, 1997, s. 438; Jerome, Giuse, Gish, Sahte ve Dietrich, 2001, s. 178).

1996'da bir kütüphanecinin Yoğun Bakım Ünitesinde vizitelere katılmasıyla başlatılan program, bugün CICS adıyla, yedi deneyimli klinik kütüphanecisinin 11 ayrı birimde hizmet vermesiyle gerçekleştirilmektedir. Dört kütüphaneciden her biri sırasıyla Diyabet Merkezi, Yenidoğan, Çocuk ve Cerrahi Yoğun Bakım Ünitelerinde; biri Meme Kanseri Ünitesi ile Tıbbî Yoğun Bakım Ünitesinde; biri Nöroloji/Nöroşirürji Yoğun Bakım Ünitesi ile Psikiyatri Hastanesinde; biri ise Acil Tıp, Klinik Araştırma Merkezi ve "Morgan Service" adlı bir birimde klinik ekiplerinin üyeleri olarak hizmet vermektedirler. Kütüphaneciler hizmet verdikleri birimlere ilişkin bilgi erişimde uzmanlaşmışlardır (Clinical Informatics Consult Service-CICS, 2008).

Başlangıç yıllarından beri program, kütüphanecilerin kütüphane kültüründen klinik kültürüne geçmelerini gerektirmiştir. Klinik kültüründe verimli olabilmek için kütüphanecilerin tıp ve hemşirelik okullarından bazı klinik derslerini almaları sağlanmıştır (Giuse, 1997, s. 437). Ekip anlayışına ve sürekli öğrenmeyi destekleyen bir kurum kültürüne bağlı olan kütüphaneciler, genellikle hizmet verecekleri uzmanlık dallarını kendileri seçerler, seçtikleri dalın ortamlarında vizitelere çıkarlar, bu dalın terminolojisini, uygulama süreçlerini, temel bilgilerini öğrenirler (Giuse ve diğerleri, 1998, s. 413).

CICS kütüphanecileri "kaliteyi süzme" kavramının geleneksel olmayan niteliğine dönük bir bakış açısıyla vizitelerde sundukları 
hizmetin düzeyini yükseltmişlerdir. "Süzme" veya "filtreleme" literatür taramaları için kullanılan, genellikle dizin, öz dergisi ya da bibliyografik veri tabanlarının denetimli dizinleme dillerini ve diğer tarama parametrelerini programlı, sistemli, bazen de sezgisel olarak kullanmayı işin içine katan bir kavramdır. CICS programında kütüphaneciler vizitelerde sorulan her bir soru için taramalarını bu şekilde süzerek yaparlar ve gözden geçirilecek ilk makaleler grubuna erişirler. İçlerinden soruya yanıt verebilecek en anlamlı makaleleri seçerler, aralarından tekrar en ilgili olanları belirleyerek okurlar ve yeniden süzerler. Okunan ve süzülen makale sayısı genellikle iki veya üçtür. Bunlardan eldeki klinik vakayla en ilgili pasajları işaretlerler. Daha sonra bu pasajları sentezleyerek birer paragraflık özetler yazarlar. Vizite esnasında görülen belli bir hastanın durumuna uygun olacak şekilde hazırlanan bu özetler, tam metin kopyalarına iliştirilerek ekiptekilere sunulur. Özetlerde farklı makalelerdeki çelişen görüşlere, önerilen tedavinin tıbbî denemeler sonucu erişilen bulgulara dayanıp dayanmadığı gibi hususlara dikkat çekilir (Giuse, 1997, s. 438; Giuse ve diğerleri, 1998, s. 413; Jerome ve diğerleri, 2001, ss. 178-179; CICS, 2008). Süzmenin bu düzeyi VUMC'deki KTK'nin can alıcı bir öğesidir ve kütüphanecileri klinik ortamlarına taşıyan değerin somut bir göstergesidir. Vakayla doğrudan ilgili olarak tıp literatüründen en anlamlı bulguları, özellikle de en güçlü kanıtları içeren özetler, başta hekimler olmak üzere ekiptekilerin kanıta dayalı isabetli kararlar vermelerini kolaylaştırır. Kütüphanecilerin ortaya çıkardıkları katma değerli belgeler, onların viziteler sırasındaki katkısını somutlaştırarak çaba, bilgi, beceri ve profesyonelliklerini sergiler (Giuse ve diğerleri, 1998, ss. 413-414).

Karmaşık sorulara yanıt veren görüşleri temsilen, süzülmüş, sentezlenmiş enformasyon paketlerini hekimlere ve diğer ekip üyelerine sağlayan CICS, KDT yaklaşımının kilit bir aracı olarak sürdürülür. CICS, belli bir hastanın klinik koşullarıyla ilgili araştırma kanıtlarının birleştirilmesine ve kararların kanıtlara dayanılarak verilmesine olanak getirmektedir. Kütüphanecileri yalnızca bir bilgi aracısı olmaktan çıkaran ve bilgi sentezleyicisine dönüştüren CICS onlara yeni bir rol vermektedir. Deneyimlerin gösterdiği gibi, genellikle sorularını yanıtlamak için anlamlı materyalin küçük bir bölümüyle yetinmeyi tercih eden klinisyenlere böyle bir programla 
büyük bir olanak sunulmaktadır. Karmaşık sorulara yanıt getirebilmek için kapsamlı, sistemli, programlı bir tarama, erişme, süzme, sentezleme ve özetleme etkinliğine girişen kütüphaneciler, literatürdeki ilgili kanıtlara değer biçerek, eldeki hastanın durumuna uygun, varolan en iyi kanıtları ilgilisine sunarlar ki bunlar için klinisyenlerin zaman ayırabilmeleri güçtür (Jerome ve diğerleri, 2001, ss. 178-179). Söz konusu program, kütüphanecinin sürecin bütün işlemlerinde hekimin yerine geçen kişi olması nosyonunu geliştirmek için tasarlanmıştır. Katma değerli hizmetleriyle kütüphaneci, klinisyenleri kendi başlarına söz konusu aşamaları yerine getirmekten kurtarır. Kütüphaneciler karmaşık olmayan, daha hızlı yanıtlanabilecek sorulara yönelik olarak, vakayla ilgili kaynak seçimi ve tarama stratejisi oluşturma yardımı sağlarlar, VUMC elektronik kaynaklarını kullanarak eğitim verirler (CICS, 2008).

Düzenlenen aylık eğitim konferanslarına katılan kütüphanecilere denetimli dizinleme dillerinin özellikleri ve tıbbî terminoloji öğretilirken, veri tabanlarını tarama, erişilenleri analizleme, süzme, yorumlama, makalelerin uyguladığı araştırma tasarımlarını değerlendirme, makalelerin sağladığı kanıtları bulma, kanıtlara eleştirel yaklaşımlarla değer biçme, temel verileri sentezleme, bilgiyi doğru bir şekilde özetleme vb. ile ilgili bilgi ve beceriler kazandırılır. Kütüphanecilerin bu iş için gerekli yetenekleri, viziteler esnasında elde ettikleri bilgi ve becerilerle geliştirilir (Jerome ve diğerleri, 2001, ss. 178-179).

Kütüphanecileri kritik sağlık bakımı ortamlarına taşıyan CICS, klinisyenlerin KDT uygulamaları için gerekli olan hastaya özgü bilgiyi tam zamanında ve yerinde sağlayarak onların doğru karar vermelerini kolaylaştırmayı amaçlamaktadır. Bu amaçla son yıllarda VUMC ağı ile sınırlı bir erişim sağlayan bir Kanıta Dayalı Site (Evidence Based Site) oluşturulmuştur. Kütüphanecilerin uzmanlıklarından yararlanabilmek, harcanacak zaman ve çabayı azaltmak için kullanılan bu sitede, viziteler esnasında alınan bütün karmaşık soruların yanıtları, süzülmüş kimlikleri ve özetleriyle birlikte yer almaktadır. Kütüphanecilerin soruları yanıtlayabilmek için kullandıkları tarama stratejileri bir güncelleştirme butonuyla doğrudan PubMed'le bağlantılandırılmakta ve 0 stratejiler doğrultusunda PubMed'de yer alan güncel kimliklere 
erişilebilmektedir. Ayrıca, tıp literatüründeki en anlamlı ve en güncel görüşlere erişebilmek için sorularla ilgili belgeler altı ayda bir güncelleştirilmektedir (CICS, 2008).

VUMC'de CICS modeline ek olarak Hastalara Yönelik Enformatik Danışmanlığı Hizmeti (Patient Informatics Consult Service-PICS) ile klinik kütüphanecilerinin vizitelerde hastalar ve yakınlarına da uygun bilgileri bulmaları sağlanmaktadır (Williams, Gish, Giuse, Sahte ve Carrell, 2001, s. 186; Koonce, Giuse, Beauregard ve Giuse, 2007, s. 77). Bu örnekte olduğu gibi, KTK'nin bazı uygulamalarında hastaların ve yakınlarının bilgi gereksinmelerini karşılamak suretiyle hizmet kapsamı genişletilmektedir. Ayrıca VUMC'de CICS modelinin uyarlanmasıyla yaratılan Araştırmaya Yönelik Enformatik Danışmanlığı Hizmeti (Research Informatics Consult Service-RICS) ile araştırmacılara gereksinme duydukları noktada ve zamanda hizmet sunulmaktadır (Lyon, Giuse, Williams, Koonce ve Walden, 2004, s. 189). Bilgiyi iş akışıyla birleştiren CICS, PICS ve RICS programları, kütüphanecinin yatak başında veya araştırma ortamında bilgi gereksinmelerini belirlemesini ve karşılamasını sağlamaktadır. CICS ve RICS kütüphanecilerin klinik tıp ve moleküler biyoloji/genetik hakkında derinlemesine bilgi edinmelerine, eleştirel değer biçme ve tarama becerilerini bilemelerine olanak getirmektedir (Vanderbilt University Medical Center-VUMC. The Eskind Biomedical Library, 2008).

$\mathrm{Bu}$ programların günümüz KTK programlarının en ileri düzeylerini temsil eden örnekler arasında olduğu belirtilebilir. KTK, belki de adına uymayarak, tıbbî araştırma ortamlarında da varlığını hissettirmektedir.

\section{LATCH:}

Hasta dosyasına iliştirilmiş literatür anlamına gelen LATCH, 1967'de Washington Hastane Merkezi'nde KTK hizmetlerinin öncüsü olarak ortaya çıkmıştır (Cimpl, 1985, s. 24). Bu hastanede 1967-1975 arasındaki LATCH uygulamasını kaleme alan Sowell (1978, ss. 218-219)'e göre LATCH, bir hastanın hastalığının bazı yönleriyle ilgili birkaç iyi makalenin, o hastayla ilgilenen herhangi bir sağlık bakımı personelinin isteği üzerine, hastanın dosyasına iliştirildiği bir uygulamadır. Genellikle, önce hekim veya diğerleri hastayla ilgili 
literatür isteklerini yazarak onun dosyasına koymakta, bu istekler sonradan bir birim görevlisi tarafından kütüphaneye iletilmektedir. LATCH belli bir hasta problemine yönelik olarak yapılan taramalardan elde edilen bir anlamlı makaleler grubunun hasta dosyasına iliştirilmesini sağlayarak vakayla ilgilenenlerin literatüre kolayca erişmesine olanak getirir. Vaka için acil çözüm gerekiyorsa LATCH taramalarına öncelik tanınır. Hasta taburcu olduktan sonra LATCH destesi kütüphanede gelecekteki olası kullanımı için sınıflandırılarak saklanabilir (Demas ve Ludwig, 1991, s. 18). Washington Hastane Merkezi uygulamasında LATCH paketleri kütüphaneye döndükten sonra, kataloglanarak, konu başlıkları ve NLM sınıflandırma numaraları verilerek kitaplarla birlikte raflardaki yerlerini almışlardır. Böylece kütüphanenin klinik tıp dermesi artırılmıştır. Bu paketler yeni bir LATCH isteği olduğu zaman güncel kimlikler eklenerek istek sahibine iletilmiştir (Sowell, 1978, s. 221).

Her ne kadar LATCH kütüphanecinin vizitelere katılmasını mutlaka gerektirmiyorsa da, Algermissen (1974, s. 355) probleme dönük olan bu bilgi iletim tekniğinin, kütüphanecinin vizite ekibinde yer almasını şart koştuğunu ileri sürmüştür. UMKC'de ekiplere sunulan başarılı LATCH hizmeti sürecinde, istek üzerine yapılan taramalar sonucunda erişilen kimliklerin ve bunlara ait belgelerin analiz edilmesi sağlanmış, hastaya ilişkin probleme çözüm getiren kaliteli enformasyonun dosyalara iliştirilmesi için çaba harcanmıştır. Hatta belli bir hastalığı daha derin biçimde çalışmak isteyenler için ek kimlikler ve bilgiler bulunmuştur. Clevesy (1980)'nin küçük bir hastanedeki LATCH uygulaması da ilginçtir. Diğer taraftan, Wolf, Chastain-Warheit, Easterby-Gannett, Chayes ve Long (2002, ss. 42-43) ABD'de bölgesel bir sağlık merkezinin Abington Memorial Hospital adındaki bir öğretim hastanesinde 1984'de özellikle hemşirelerin bilgi gereksinmelerini karşılamak üzere sınırlı birimlerde pilot proje olarak başlatılan, daha sonra genişletilerek hastanenin bütün klinik birimlerinde uygulanan başarılı bir LATCH programına değinmişlerdir. Bu uygulamada 1984-2000 arasında 10.000 LATCH isteği karşılanmıştır.

Tüm KTK girişimlerine uygulanabilir nitelikte olan LATCH'in başta hekimlere ilgili bilgiyi sağlamasının hastanın daha iyi bir sağlık 
bakımı görmesini etkilediği varsayılmaktadır (Sowell, 1978, s. 218; Cimpl, 1985, s. 24).

3. Vaka Sunumu Toplantılarına Katılma:

Bugün tıp danışma kütüphanecilerinin sorumluluklarının önemli bir bölümü, klinik ekiplerine katılmalarıyla gerçekleştirilmektedir. Vaka sunumu/takdimi toplantıları, tıpkı hasta viziteleri gibi, kütüphanecinin ekip üyeleri arasında yer aldığı uygulamalardır. Bu uygulamalar özellikle iç hastalıkları tıbbında önemli eğitimsel geleneklerden sayılırlar. "Sabah raporu" (morning report) adıyla da anılabilen bu toplantı tipi, esas itibariyle yatan hastaların durumlarını, tanı ve/veya tedavilerini tartışmak üzere bir hastane bölümü başkanı ve hekimlerinin katıldığı, çoğunlukla hasta koğuşlarına yakın salonlarda gerçekleştirilen vakaya dayalı bir konferansı ifade eder. Vaka sunumu toplantısı genellikle, hekimlere doğru tanı koymayı öğreten, onların tanı koyma becerilerini ve problem çözme yeteneklerini geliştiren karmaşık bir eğitimsel süreçtir. Bu sürecin önemli özelliklerinden biri de vakaları gerçek zamanlı formatta sunması nedeniyle öğrenmeyi hızlandırabilmesidir. Belli bazı ilkeler çerçevesinde yapılmakla birlikte, vaka sunumu toplantıları yapı ve stilleri açısından hastaneler arasında, hatta hastane bölümleri arasında farklılık gösterebilmektedir; toplantılarda hastaneye bir gece için yatan hastalara ilişkin kısa tartışmalardan, yeni veya önceden yatmış olanların olağandışı bulgularının sunulduğu ayrıntılı tartışmalara kadar çeşitli uzunluktakiler yer alabilir (Banks ve diğerleri, 2007, s. 381). Vakalar hakkında en kapsamlı tartışmaların yapılabildiği, hasta bakımı, problem çözme ve sürekli eğitim stratejilerinin plânlandığı bu toplantılara yalnızca hekimler değil, sağlık bakımı ekibinin diğer üyeleri de katılabilirler (Marshall ve Hamilton, 1978, s. 422).

Kütüphanecinin toplantılara katılarak sağladığı bilgi desteği yıllar içinde giderek benimsenmiştir. Vaka sunumu toplantılarında klinik kütüphanecisinin etkisini ele alan Barbour ve Young (1986), Virginia Hampton'daki askerî bir tıp merkezinin bir bölümündeki toplantılarda kütüphanecinin haftada bir sağladığı desteğin toplantıların eğitimsel değerini yükselttiğinden söz etmişlerdir. Bir vakanın sunulmasından sonra, o vakayla ilgili literatür taraması 
kütüphaneci tarafından yapılarak, erişilenler kısa zamanda ilgilisine iletilir. Böylece kütüphaneci, bu tip toplantılarda önemli bir rol üstlenerek KTK yaklaşımlarından birini daha uygulamış olur. Genellikle, tartışılan vakaların yatak başında incelendiği, kütüphanecinin de katıldığı viziteler toplantıları izler. Bu süreçlerde kütüphanecinin sağladığı bilgi, hekim ve diğerlerinin hastanın şifa bulması yönünde daha doğru kararlar vermelerini etkileyebildiği için, kütüphanecinin hasta sağlığına önemli bir katkıda bulunduğu belirtilebilir. Son yıllarda kütüphanecilerin kanıta dayalı kaynaklardan yaptıkları taramaları işin içine katan vaka sunumu toplantıları, hasta bakımı uygulamalarına KDT modelini eklemenin güncel ve etkili bir aracı olmaktadır (Banks ve diğerleri, 2007, ss. 381-382, 385).

Wagner ve Byrd (2004)'in yukarıda sözü geçen tablosu kütüphanecinin vaka sunumu toplantılarına katılımıyla gerçekleştirilen programlar hakkındaki literatüre yönlendirirken, konuya ilişkin özlü bilgi alınmasını sağlamaktadır. Winning ve Beverley (2003) de kütüphanecinin bu toplantılara katılımını ele alan literatür örneklerini vermektedir. Birkaç örnek uygulama bu yaklaşımın daha iyi anlaşılmasını sağlayabilir:

\section{Kanada Ontario'daki McMaster Üniversitesi Tıp Merkezi Hastanesinde KTK Uygulaması:}

$\mathrm{Bu}$ hastanede Gastroenteroloji Programı kapsamında 1975'de başlatılan bir KTK projesi, yalnızca hekimlerin ve diğer sağlık profesyonellerinin oluşturduğu ekiplerin değil, yatan hastaların ve yakınlarının da en güncel literatüre erişerek bilgilenmelerini amaçlamıştır. Ekip ruhuna, hastaların ve yakınlarının bilgilenme hakkına önem veren Gastroenteroloji Bölümü, ekibinde, Tıp Merkezi Kütüphanesi'nden bir kütüphanecinin yarı zamanlı olarak yer alması önerisinde bulunmuştur. Kütüphaneci bütün vakaların tartışıldığı toplantılara haftada bir katılmış, belli bir vakaya ilişkin bilgi gereksinmelerini belirlemiş, toplantıları izleyen vizitelerde de belirlemelerini sürdürmüştür. Daha sonra taramalarını yaparak, her bir soruyla ilgili bir-iki seçilmiş makalenin fotokopisini toplantı odasındaki panoya iliştirmiştir. Makaleler bir hafta sonra kaldırılarak koğuş içinde bir yerde Tıbbî Konu Başlıklarına (Medical Subject Headings-MeSH) göre sıralanmış, böylece yerinde bilginin 
edinilmesine bir süreklilik kazandırılmıştır. Kütüphaneci toplantıda durumları tartışılan hastaları daha sonra ziyaret ederek, hastalıklarıyla ilgili bir bilgi isteyip istemediklerini sormuş, istiyorlarsa sorularına dayanarak düzeylerine uygun materyali kendilerine sunmuştur. Ancak önceden materyalin doğru ve hastaya uygun bilgiyi içerip içermediği ekip üyelerinin katkısıyla denetlenmiştir. Verilen hizmetin değerlendirilmesi aşamasında enformal görüşmeler yoluyla ekip üyelerinden ve hastalardan kütüphaneci katkısı hakkında olumlu geribildirimler alınmıştır. Özellikle hekimler ve diğer ekip üyeleri hizmeti vakalarla ilgili güncel literatüre eriştirmede başarılı bulduklarını belirtmişlerdir. Aslında hizmet sıkı bir şekilde yalnızca yatan hasta vakalarıyla ilgili makale sağlamaya dayandırılmıştır. Bununla birlikte, kütüphanecinin varlığı sağlık personelinin kütüphane hizmetlerini daha etkin bir şekilde kullanmalarına yol açmıştır. Vaka dışı amaçlarla kütüphane kullanımı ve literatür taramasının yolları da ekip üyelerine öğretilmiştir. Vaka sunumu toplantılarına katılması, kütüphanecinin klinik etkinlikleri ve bilgi gereksinmeleri hakkında ilk elden fikir edinmesini, klinik tıp bilgisini ve terminolojisini geliştirmesini sağlamış, ona kendi meslekî varlığının ve kütüphane materyalinin doğrudan hasta bakımına katkıda bulunabildiğini göstermiştir (Marshall ve Hamilton, 1978, ss. 420, 422-424).

\section{Delaware'deki Christiana Sağlık Bakımı Sistemindeki İki Hastanede KTK Uygulaması:}

Bu uygulama 1990'ların başlarından itibaren kütüphanenin desteği ile yürütülmüştür. Uygulama, Tıp Departmanı'nın danışma kütüphanecilerinin "sabah raporu" adını alan vaka sunumu toplantılarına her gün katılmaları ve vakalarla ilgili literatür taraması yapmaları önerisiyle başlatılmıştır. Kütüphaneciler bu toplantılara ancak haftada bir-iki kere katılabilmişler, toplantı sonrasında hekimlerle görüşerek tarama konularını saptamışlar, yaptıkları taramaların sonuçlarını, seçilmiş makalelerin kimlik bilgilerini ya da tam metinlerini veya kitaplardan ve çevrim içi kaynaklardan seçilmiş bölümleri öğleye kadar kendilerine iletmişlerdir. İletimde çok sayıda e-posta kullanılmıştır. Vaka sunumu toplantıları arasında fark vardır; bazılarında tek bir vaka üzerinde ayrıntılı olarak durulurken, bazılarında bütün hasta vakalarını tartışabilmek için eşit zaman 
ayrılmıştır. Kütüphaneciler toplantılardaki farklılıklara uyum göstererek hizmet vermişlerdir. Bütün toplantı katılımcıları kütüphanecilerin tarama hususundaki uzmanlıklarına güvenmiş, hasta mahremiyetine saygılı olacaklarına inanmışlardır. Ekiptekiler kütüphanecilere soru sormak için birbirlerini teşvik etmişlerdir. Hangi konuların taranacağına dair karar, doğrudan kütüphanecilere bırakılabilmiştir. Zaman içinde hekimlerin KDT uygulamasına ilgi duyması üzerine kütüphaneciler kanıt içeren literatüre erişmek için Best Evidence, Cochrane Database of Systematic Reviews, Database of Abstracts of Reviews of Effectiveness gibi KDT veri tabanlarını taramaya başlamışlardır. Toplantı katılımcılarının KTK hizmeti hakkındaki geribildirimleri olumlu olmuştur (Wolf ve diğerleri, 2002, ss. 43-44).

\section{Louisiana Eyalet Üniversitesi Sağlık Bilimleri Merkezi Hastanesinde KTK Uygulaması:}

$\mathrm{Bu}$ hastanede haftada beş sabah 8.00-9.00 arası İç Hastalıkları Bölümünde yapılan ve "sabah raporu" adıyla anılan vaka sunumu toplantılarının amacı hekimlere, sunulan vakayı mantıksal olarak nasıl analiz edeceklerini, bir tanı ve/veya tedavi kararına ulaşabilmeleri için doğru stratejiyi nasıl belirleyeceklerini öğretmektir. İç Hastalıkları eğitim programının temellerinden biri olan bu toplantılara yaklaşık 24 kişilik bir ekiple birlikte bir danışma kütüphanecisi katılmaktadır. Standart olarak tek bir yatan hasta vakası her sabah bir hekim tarafından sunulmaktadır. Hasta merkezli diyaloğu kolaylaştırmaktan sorumlu olan bu hekimin sunumundan sonra, diğerlerinden vakanın tanısal bilmecesini çözmeleri, zaman kalırsa tedavi seçeneklerini tartışmaları beklenmektedir. Her toplantıdan sonra kütüphaneci, biri sunumu yapan hekim olmak üzere iki hekimin ortaklaşa hazırladıkları iki soru doğrultusunda çevrim içi bir tarama yapmakta, eriştiklerini ekiptekilere kısa sürede iletmektedir. Kütüphaneci toplantıya katılmak için günde bir saat, tarama için bir saat, eriştiği uygun makaleleri iletmek için de belirli bir süre ayırmaktadır. Söz konusu hastanede vaka sunumu toplantılarına kütüphaneci katılımının, hastanın hastanede yatış süresini kısaltmada ve hastane masraflarını azaltmada etkili olup olmadığını belirlemek üzere bir araştırma yapılmış ve elde edilen bulgular bu katılımın her iki 
hususta da etkili olduğunu ortaya çıkarmıştır. Bu araştırma, toplantıların kütüphaneci değerinin anlaşılmasını sağladığını, kütüphaneciye hekimlere tarama becerilerini geliştirebilmeleri için yardımcı olma olanağını getirdiğini de belirlemiştir. Kütüphanecinin sağladığı bilgiden sonra hekimlerin daha farklı tahliller istedikleri, tanı ve/veya tedavi kararlarını değiştirdikleri saptanmıştır. Kütüphanecinin vaka sunumu toplantılarına katılımının ve bulduğu bilginin, özellikle kanıt içeren bilginin, söz konusu kurumda da toplantıların eğitimsel etkisini güçlendirmekle kalmayıp, kanıta dayalı kararları pozitif yönde etkileyerek hasta bakımını geliştirdiği, kurumun kütüphanesi ile İç Hastalıkları Bölümü'nün ortak çabaları sayesinde bu pozitif etkilere ulaşıldığı belirlenmiştir. Bu özgün "sabah raporu" modeli hastalık problemlerine güncel ve kanıta dayalı bir yaklaşım getirmektedir (Banks ve diğerleri, 2007, ss. 381382, 386-387).

Vaka sunumu toplantıları dışında, kimi kez bu toplantılarla benzer nitelikler taşıyan, klinik konferansı, eğitim veya bölüm konferansı adlarını alan ve çeşitli aralıklarla yapılan toplantılarda da klinik kütüphanecisinin katkılarını görmek mümkündür.

4. Bilgiyi İstenmeden Sunma:

Hasta bakımıyla, yani tanı, tanısal testler/tahliller ve tedaviyle ilgili bir okuma materyali grubunun, istenmeden önce hasta dosyalarına iliştirilmesi esasına dayanan proaktif programlar çeşitli hastanelerde uygulanmıştır. Bu tip programlar "istek üzerine" verilen hizmete odaklanan KTK programlarından farklıdır. Örneğin Boston'daki üç hastanede uygulanan Hasta Bakımına İlişkin Okuma Programı (Patient Care Related Reading Program-PCRRP)'nda ilgili makaleler önceden seçilip paketlenerek rutin olarak hasta dosyalarına yerleştirilmiş veya belli bir klinisyene sunulmak üzere hazırlanmıştır. Her bir paketin önceden seçilmiş bir konudaki makaleleri içermesine dayandırılan bu programın amacı, literatürü güncel vakalarla ilişkilendirmek, literatürün hekimler tarafından kullanımı üzerinde çalışmak, okunan literatürün hasta bakımındaki doğrudan etkilerini belgelendirerek kanıtlamak olmuştur (Hutchinson, Malamud, Stearns ve Moulton, 1981, s. 236). Cimpl (1985, s. 24), Los Angeles'deki California Üniversitesi (University of 
California at Los Angeles-UCLA)'nde Norris Tıp Kütüphanesinin de önceden paketlenen bilgi yaklaşımını benimsediğinden söz etmektedir.

Çeşitli yaklaşımlarla gerçekleştirilen KTK programlarının temel ve ortak amacının, tıp ve sağlık bilimleri kütüphaneciliği hizmetlerini, özellikle kütüphanecinin literatür taraması uzmanlığını gereksinim duyulan hasta bakımı ve araştırma ortamlarına taşımak, böylece karar verme, araştırma ve eğitimi desteklemek olduğu görülmektedir. Yakın zamanlarda başta klinisyenlerin literatürden alınan en iyi kanıtları hasta bakımı kararlarıyla birleştirmeleri hedeflenmiştir. Bu amaçlar doğrultusunda uygulanan KTK programlarının temelde yöntem, nitelik, süre ve maliyet açısından ne derecede başarılı olduklarını belirlemek amacıyla gerçekleştirilen çok sayıda değerlendirme çalışması, değinilenlere ek olarak, literatürde yer almaktadır. Cimpl (1985), Winning ve Beverley (2003), Wagner ve Byrd (2004) önemli buldukları değerlendirme çalışmalarının amaç ve bulgularını etraflıca tartışmışlardır. Değerlendirme çalışmalarının bulguları KTK hizmetlerinin avantaj ve dezavantajlarının belirlenmesini sağlamıştır.

\section{Klinik Tıp Kütüphaneciliği Hizmetlerinin Avantaj ve Dezavantajları}

KTK hizmetlerinin birçok yararı yukarıda kısmen ele alınmıştır. Özellikle klinisyenlerin zamanında bilgilenmesini sağlayan KTK hizmeti, onların hastanın tedavisine yönelik isabetli kararlar vermelerini etkileyerek hasta sağlığına dolaylı bir katkıda bulunur. KTK'nin bu katkısı, toplumun hasta bireylerinin iyileştirilmesine yönelik önemli bir yararı simgeler. Hizmetin, tıbbın klinik ve klinik öncesi bilimlerinin ve çeşitli sağlık alanlarının araştırmacıları için zamanında sunduğu bilgi desteği ise, bu bilim ve alanların geliştirilmesine destek verir.

KTK hizmetini değerlendiren çeşitli çalışmalara ve/veya kendi çalışmalarına dayanarak Cimpl (1985, ss. 23-24, 26), Veenstra (1992, ss. 19-21), Klein, Ross, Adams ve Gilbert (1994, s. 489), Giuse ve diğerleri (1998, ss. 413-415), Davidoff ve Florance (2000, ss. 996-997), Winning ve Beverley (2003, ss. 11, 16-17), Wagner ve Byrd (2004, ss. 14-16), Banks ve diğerleri (2007, ss. 381, 383-384) 
gibi yazarlar hizmetin avantajlarını ayrıntılı olarak saptamışlardır. Bu literatür ışığında avantajlardan önemli görülenleri sunmada yarar vardır; KTK, katma değerli yaklaşımlarıyla, ilgili literatüre erişime, literatürü analizleyip sentezlemeye vakti olmayan meşgul hekimlere, sağlık ekibinin diğer üyelerine ve araştırmacılara büyük bir zaman tasarrufu sağlar. Klinik kütüphanecilerinin uzmanlığından yararlanmayı tercih etmeyerek tarama ve diğer işlemleri kendilerinin yapmaya çalışmaları, bu kişilerin zamanlarını tıp ve sağlık adına verimli kullanamadıkları anlamına gelebilir. Diğer taraftan KTK hizmeti, tanı koyma, tanısal testlerin/tahlillerin seçimi ve tedavi şeklini belirlemeyi içeren hasta bakımı hakkındaki hekim düşüncelerini etkilemiş, hasta bakımını geliştirmiştir. Hizmet, ilâç seçiminde etkili olmuş, anlamlı bilginin çabuk bulunmasını sağladığı için gereksiz testler/tahliller zamanında engellenebilmiştir. Yeni veya bilinmeyen bilginin hekimlerin kendilerini güncelleştirmelerinde, öğrenmelerinde ve kararlarını değiştirmelerinde etkisi görülmüştür. KTK özellikle hekimler arasında bilgi paylaşımını hızlandırmış, isabetli ortak kararların alınmasını sağlayabilmiştir. Ayrıca KTK hizmetlerinin enfeksiyonu, hatta ölümü engellediği, hastaya tavsiyelerde etkili olduğu belirlenmiştir. Hastanın hastanede yatış süresini kısaltarak masraflarını azalttığı saptanmıştır. KTK hizmetleri, hekimler, diğer sağlık personeli ve araştırmacıların kütüphane kaynak ve hizmetlerinden haberdar olmalarını, kütüphaneden daha çok yararlanmalarını sağlamıştır. Kütüphane kullanımına, bilgi okuryazarlığı becerilerini geliştirmeye, bibliyografik veri tabanlarından etkin bir şekilde yararlanmaya yönelik eğitim programlarına katılımlarını artırmış ve bilgi arama davranışlarını olumlu yönde etkilemiştir. Hekim ve diğerlerinin kütüphanecinin önemli rolünü kabul etmeleri bu hizmetler sayesinde güçlenmiştir. Hizmet yalnızca hasta bakımı için değil, vaka sunumu, öğretim, yönetim, araştırma ve yayın etkinlikleri için hekim ve diğerlerinin gereksinim duydukları bilgiyi elde etmelerini kolaylaştırmıştır. Öte yandan KTK hizmeti, sürekli tıp ve sağlık eğitiminin kalitesinin yükseltilmesinde etkili bir rol oynamıştır. Ayrıca tıp ve sağlık alanları öğrencilerinin eğitim süreçlerine olumlu katkılar getirmiş, onları hasta bakımına ilişkin yardımcı eğitime özendirmeyi sağlamıştır. Hizmet KDT uygulamalarına karşı duyarlı bir yaklaşımla sunulduğunda, bu uygulamaların giderek benimsenmesinde de etkili 
olmuştur. Bunların yanı sıra, KTK'nin hastalar ve ailelerinin hastalık hakkında bilgilenmelerini sağlayan insancıl yönünü göz ardı etmemek gerekir. Bunun, hasta davranışları üzerindeki olumlu etkileri belirlenmiştir. KTK'nin kütüphanecilik uygulamalarının kapsamını genişlettiği, katma değerli hizmetler sunmanın yollarından birini hayata geçirdiği kesindir. Hizmetin kütüphaneciye getirdiği avantajların başında, onu danışma masasından uzaklaştırarak aktifleştirmesi gelir. KTK, kütüphanecinin klinik ve araştırma ortamlarını, hastalık ve vakaları daha iyi anlamasını sağlayarak, tıbbî terminoloji ve prosedürler bilgisini artırmasına yol açar. Bu bilgi, kütüphanecinin hekimler ve diğerleriyle iletişimini kolaylaştırırken, kendine güven duygusunu artırır. Bilgi gereksinmelerini yerinde ve yaşayarak görmesini sağlar. Tıp ve sağlık literatürünü yorumlama yeterliliğini kazandırır. KTK hizmeti, KDT ile bütünleştirilerek sunulduğunda, kütüphanecinin hastanın özgün durumuna en uygun kanıtlara erişme ve değer biçme yetisini güçlendirirken, tarama, analizleme, süzme, yorumlama ve sentezleme becerilerini geliştirir; onu, bu yetilerini iyice geliştirebilmesi için gerekli olan bir KDT kütüphaneciliği eğitimi almaya özendirir. KTK kütüphanecinin üst düzeyde meslekî becerilerini kanıtlamasına fırsat verir. Onun hasta bakımı ve araştırma ortamlarında rolünü kabul ettirmesine, vazgeçilmez bir ortak olarak benimsenmesine yol açar. Rolünü artıran kütüphanecinin daha büyük bir meslekî doyuma ulaşmasına olanak getirir. Onun kurum kültürüne daha çok bağlanmasını sağlar.

Bu avantajlara karşılık, KTK'nin dezavantajları veya zayıf yönleri de vardır. Bunlar, çeşitli değerlendirme çalışmaları baz alınarak Cimpl (1985, s. 26), Davidoff ve Florance (2000, ss. 996997), Plutchak (2000, ss. 391-392), Winning ve Beverley (2003, ss. $11,16,19)$ gibi yazarlar tarafından belirlenmiştir. Belirlenen dezavantajların önde gelenleri arasında, KTK hizmetinin maliyetinin yüksek olması, hizmet için genellikle ek ödenek sağlanamaması, hizmetin tıp ve sağlık bilimleri kütüphanesine fazlasıyla bağlı olması ve kütüphanenin bütçe kısıtlamalarından etkilenmesi, kütüphanedeki danışma hizmetinin etkinliğini azaltması, bazı kütüphanecilerin işi benimsememesi, ek personeli gerektirecek kadar fazla iş yükünün ortaya çıkması, hizmetin zaman alıcı olması, 
kütüphanecinin sağlık ekibinin bir üyesi olarak her zaman benimsenmemesi ve ekibin üye sayısını kabartması, kütüphanecinin iyice eğitilmeden KTK programlarına katılması ve tıbbî terminoloji bilgisinin yeterliliğinin sorgulanması, hekimlerin bilgi yardımı istemedeki kararsızlıkları, hizmetin hastanenin bütün bölümlerine verilememesi ve kurumun malî, kurumsal, kültürel özellikleriyle sınırlı olması gibileri vardır.

Değinilen dezavantajların yanı sıra hacimce çok artan ve artışını sürdüren literatürün sağlık bakımı ve araştırma ortamlarına yeterince iyi taşınamaması gibi gerekçeler, Davidoff ve Florance (2000)'ın enformasyonistlik mesleği önerisini getirmelerine yol açmıştır. Kısacası enformasyonist melez bir meslekten kişidir. Bu yazarlara göre enformasyonistin hem tıp ve sağlık bilimleri kütüphaneciliği ve KDT kütüphaneciliği, hem de klinik tıp ve sağlık alanları hakkında bilgi ve beceri sahibi olması gerekmektedir. Temel meslek eğitimlerini kütüphanecilik veya sağlık alanlarında almış olanlar enformasyonist olmaya aday olsalar da, bu kişilerin bütünleşik bir eğitim programıyla yeniden eğitilmeleri öngörülmüştür. Alkan (2002a) KTK'nin bazı avantaj ve dezavantajlarıyla birlikte enformasyonistlik mesleği önerisine çeşitli yaklaşımlarla açıklık getirmiştir. Bugün enformasyonistlik farklı tıp ve sağlık kuruluşlarında denenmekte ve uygulamaya geçirilmektedir. KTK tabanlı hizmetlerin bu tip girişimlere sağlam bir temel oluşturdukları yadsınamaz. Örneğin VUMC'deki, CICS ve RICS hizmetleri enformasyonist modellerinin temsilcileri arasında görülmekte, kütüphanecilerin enformasyonist olarak yetiştirilmelerine özen gösterilmektedir (VUMC. Eskind Biomedical Library, 2008).

\section{Klinik Tıp Kütüphaneciliğinin Türkiye’de Uygulanabilirliği}

Son yıllarda KDT kütüphaneciliğini de işin içine katarak çok gelişen tıp ve sağlık bilimleri kütüphaneciliğinin ülkemizde istenen düzeye ulaşamadığı belirtilebilir. Tıp ve sağlık bilimleri kütüphanecilerimizin genelde, alana özgü resmî bir eğitim almaksızın uygulamalar esnasında kendilerini yetiştirdikleri görülmektedir. Bu kütüphaneciler yenilikleri izlemeye çalışarak, günün teknolojisinin, bibliyografik veri tabanlarının ve İnternet'in sunduğu erişim olanaklarını keşfederek bilgi ve becerilerini artırmak için çaba harcamaktadırlar. Ancak hâlâ 
alandaki son gelişmeler doğrultusunda yetişmek üzere sistemli ve kapsamlı Sürekli Meslekî Eğitim (SME) etkinliklerinden yararlandırımalarına intiyaç vardır. Tıp ve sağlık alanları literatürünün ve bibliyografik veri tabanlarının, İnternet'ten erişilebilen tıp ve sağlık bilgisinin artmasıyla daha da karmaşıklaşan bilgi erişim ortamı ve gelişen KDT uygulamaları, kütüphanecilerin erişimin inceliklerini kavramalarını, KDT kütüphaneciliğinin kanıtlara erişime yönelik ilke, uygulama, yöntem ve tekniklerini öğrenmelerini, güncel bilgi ve beceriler kazanmalarını gerektirmekte, ayrıca tıbbî terminoloji, anatomi, fizyoloji, epidemiyoloji, klinik ve hastalık bilgisi vb. gibi alanlarda eğitilmelerini zorunlu kılmaktadır.

KTK'nin ülkemizde etkin bir şekilde uygulanabilirliği, yukarıda değinilen türde bir eğitim alan, ek olarak KTK alanında yetiştirilen nitelikli tıp ve sağlık bilimleri kütüphanecilerinin varlığına bağlıdır. Bunun gerçekleştirilmesi için zamana intiyaç vardır. Bununla birlikte, ülkemizin hiçbir hastanesinde resmî ve etkin bir şekilde uygulanmadığı* belirlenen KTK'nin, eldeki kütüphanecilerle, varolan koşullar çerçevesinde bir şekilde başlatılması girişimlerinde bulunulabilir. Başlangıç aşamasında kütüphanecilere eğitim olanakları sunmanın çeşitli yolları arasında, KTK'nin önde gelen uzmanlarının ülkemizde seminerler vermelerini sağlamak, kütüphanecilerin MLA'nın uzaktan öğrenim kursları gibi elektronik ortamlarda sunulan KTK hizmetine yönelik SME programlarından yararlanmaları için fırsatlar yaratmak gibileri vardır. Bu yollarla ve konuya ilişkin yabancı literatürü okuyarak öğrenilenler, KTK'nin Türkiye koşullarına nasıl uyarlanabileceği ve başlatılabileceği hususunda düşünce üretiminin önünü açabilecektir. Türkçe KTK literatürünün artmasıyla, konunun benimsenmesi ve uygulamalara özendirilmesi sağlanabilecektir. Üniversitelerimizin Bilgi ve Belge Yönetimi Bölümlerinde KTK modeline ilişkin yüksek lisans ve doktora tezlerinin yapılmasının da yararı olabilecektir.

\footnotetext{
* Koç Üniversitesi Hemşirelik Okulu kütüphanecilerinin, kütüphaneyle aynı binada bulunan Amerikan Hastanesi'nde sabah 7.30 da başlayan bazı eğitimsel vaka sunumu toplantılarına çağrıldıklarında katıldıkları, bu toplantılarda kısa bir süre konuyla ilgili kütüphane kaynaklarını tanıttıkları, hizmetin tam bir KTK hizmeti olmadığı kütüphane yöneticisi Güssün Güneş’ten e-posta yoluyla öğrenilmiştir (14 Nisan 2008).
} 
KTK hizmetine başlangıç aşamasının akla yatkın bir yolu, bir kurumun, örneğin gelişmiş bir kütüphanesi, tıp ve sağlık bilimleri fakülteleri ve eğitim hastanesi olan bir üniversitenin, ilerde işin lideri olabilecek nitelikli, İngilizce bilen bir ya da birkaç tıp ve sağlık bilimleri kütüphanecisini -tercihen 2-3 yıl deneyimli danışma kütüphanecilerini- yurt dışında düzenlenen, KTK ve KDT kütüphaneciliğine özgü SME olanaklarından yararlandırması veya daha iyisi, onların yurt dışı uygulamalarını yerinde görmelerini sağlaması olabilir. İngiltere'de Sheffield Üniversitesi'ndeki Sağlık ve İlişkili Alanlar Araştırmaları Okulu (School of Health and Related Research - ScHaRR) eğitimin görülebileceği, ABD'deki VUMC Tıp Merkezi Hastanesi ise hem uygulama, hem eğitimin görülebileceği örnekler arasındadır. Böylece kurum, başlangıçta eğitim olanaklarını finanse ederek, Türkiye'deki ilk etkin KTK uygulamasına önderlik etmiş ve geleceğe yatırım yapmış olabilecektir. Eğitim alan, uygulamaları yerinde inceleyen kütüphaneciler, bağlı oldukları kurumun hastanesinde, kütüphane hizmetinin uzantısı olarak, koşullara uygun bir pilot uygulama başlatabilirler. Bu pilot uygulama bir klinik bölümünde, kütüphanecinin vizitelere veya vaka sunumu toplantılarına katılmasıyla gerçekleştirilebilir. Hangi yaklaşımın daha uygun olacağının kararı o klinik bölümü yöneticisinin görüşleri doğrultusunda verilebilir. Bir klinik bölümünde bu yaklaşımlardan biriyle pilot uygulamayı başlatabilmek için ön çalışma yapmak gereklidir; öncelikle hizmetin amaçları belirlenmeli, yapılmak istenenler saptanmalı, hizmet verilecek bölümün profili çıkartılmalı, kullanıcı toplumu tanımlanmalı, eğitime ve araştırmaya yönelik yapısı öğrenilmelidir. Hizmetin verimli bir şekilde başlatılabilmesi için kullanıcıların bilgi arama davranışlarının, karar verme alışkanlıklarının belirlenmesi gerekir. Hizmetin ifade edilmiş bilgi gereksinmeleri çerçevesinde tasarlanmasına bilhassa özen gösterilmelidir. Uygulama plânı, çalışma gün ve saatleri, iş tanımları, politika ve prosedürler belirlenmelidir. Diğer taraftan, hizmetin bölümdeki hekim ve sağlık profesyonellerine tanıtılarak pazarlanması mükemmel bir başlangıç noktası olabilir. Ancak hizmet, sunulabileceği kadar pazarlanmalıdır. Başarılı bir pazarlama bölümdeki birkaç hekim ya da sağlık personeliyle işbirliği yapılarak gerçekleştirilebilir. Bölümdekilere bilgi erişime yönelik bir eğitim verilecekse bu, pilot çalışma aşamasında plânlanmalıdır. Başlangıç 
aşamasında hastane yönetimi ve bölüm yöneticisiyle anlaşmaya varılıp hizmetin kurumsal, hukuksal, yönetsel, malî ve etik çerçevede sağlam bir zemine oturtulması çok önemlidir. Belli bir süre sonra, uygulanan hizmetin kapsamlı bir değerlendirmesi yapılmalıdır. Değerlendirme çalışması sonunda, belirlenen amaçların ne derece karşılandığı, hizmetin istenme ve kullanılma sıklığı, kullanıc üzerinde yarattığı etki, kullanıcıya verdiği güven, geribildirim sonuçları, sorulan soru sayısı ve erişilen anlamlı kimlik sayısı gibi nicel veriler ve çeşitli anlamlı istatistiksel bilgiler ortaya çıkarılabilecektir. Değerlendirmeden sonra genellikle olumlu sonuçlar alınmışsa hastanenin diğer bölümlerinde de uygulamaya geçme girişimlerinde bulunulabilir. Değerlendirme bulgularının nicel ifadesi, kurum yönetiminin hizmet için ek bütçe ayırmasını ve diğer bölümlerde de uygulama başlatılmasına destek vermesini sağlayabilecektir.

Sözü geçen lider kütüphaneciler, kuram ve uygulamaya dayanan KTK bilgilerini yurt içinde meslekî ortamlarda diğer tıp ve sağlık bilimleri kütüphanecileriyle paylaşabilir, yayın yaparak, bildiri sunarak hizmeti tanıtabilirler. Onlara SME programları kapsamında eğitim verebilirler.

Değinilenlerden anlaşılacağı üzere, Türkiye'de klinik kütüphanecisi veya onun gelişmiş modeli olarak ileri sürülen enformasyonist gereksinmesini karşılayabilmek için, öncelikle tıp ve sağlık bilimlerinde eğitim almış kişileri kütüphanecilik ve bilgi erişim alanlarında eğitmekten çok, tıp ve sağlık bilimleri kütüphanecilerini tıbbî terminoloji, anatomi, fizyoloji, epidemiyoloji, klinik ve hastalık bilgisi vb. gibi alanlarda güçlendirmeyi, bibliyografik veri tabanlarını doğru kullanma ve gelişmiş bilgi erişim becerileri kazandırmayı, kanıtlara erişim ve değer biçme üzerinde yoğunlaşan KDT kütüphaneciliğinin ve KTK'nin esasları doğrultusunda yetiştirmeyi hedefleyen eğitim programlarına odaklanılması gerekir. Kütüphanecinin KTK hizmetindeki önemli rolünü başka mesleklerden olanlara bırakmaması önem taşır. 


\section{Sonuç}

Kütüphanecinin gereksinim karşılayıcı anlamlı literatüre ve literatürdeki güvenilir kanıtlara erişim uzmanlığını hasta yatağı başına ve araştırma ortamlarına taşıyan, karar verme, araştırma ve eğitim süreçlerini destekleyen KTK hizmetleri çeşitli yönleriyle ve Türkiye'de uygulanabilirliği açısından tartışılmıştır. Bu hizmetlerin, Türkiye'de nüfusun artmasına bağlı olarak gittikçe çoğalan hasta sayısıyla iş yükü artan hekim ve sağlık profesyonellerinin gereksinme duydukları anlamlı ve güncel bilgiye ve kanıtlara erişmelerinde zaman tasarrufu sağlayacağı açıktır. KTK hizmetleri bu kesimi zaman alıcı literatür taramaları yapmaktan kurtaracak ve zamanlarını hasta bakı$\mathrm{mı}$, araştırma ve eğitim için daha verimli bir şekilde kullanmalarına olanak getirecektir. Kullanıcı taramalarını artıran yeni teknolojilerin sunduğu olanaklara rağmen, hekim ve diğerleri kütüphanecilerin doğrudan ve dolaylı olarak sağlığı etkileyen bilgiye erişimde uzman olduklarını anlayacaklardır. Ancak bunun anlaşılabilmesi için kütüphanecilerin uzmanlıklarını kanıtlamaları şarttır.

Türkiye'de tıp ve sağlık bilimleri kütüphanecileri özellikle KTK ve KDT kütüphaneciliğine odaklanan eğitim programlarıyla yetiştirilebildikleri ve KTK hizmetlerini KDT kütüphaneciliği doğrultusunda gereğince uygulayabildikleri zaman, hizmetlerin gerçek meyveleri alınabilecek, kütüphanecilerin varlığı hastalara sağlanan bakımda, tıp ve sağlık araştırmaları ve eğitiminde fark yaratabilecek, kararların isabetle verilmesinde etkili olabilecektir. Nitelikli KTK hizmetleriyle ülkenin sağlık bakımı standartları yükseltilebilecektir.

Katma değerli yaklaşımlarıyla KTK, ülkemiz tıp ve sağlık bilimleri kütüphanecileri için yeni bir meslekî seçenek sunmakta, meslekî doyuma ulaşmanın yolunu açmaktadır. Bu hizmet modeli, kütüphanecilerin tıp ve sağlık alanlarına sağlayacakları güçlü desteği, hastaların şifa bulmasına yönelik etkili katkısını müjdeler gibidir. Ülkemize özgü KTK standartları doğrultusunda hastanelerimizde birbirine benzer hizmetlerin verileceğini, bu hizmetlerin kilit rol ve becerileri belirlenen klinik kütüphanecilerimizin elinde geleceğin Türkiye'sinde geliştirilip yaygınlaştırılacağını umabiliriz. 
Çalışmamızda sunulan görüşlerin ve yönlendirilen literatürün kütüphanecilerin özgün fikirlerine kapı aralayacağını, KTK'nin ülkemizde başlatılması hususuna ivme kazandıracağını, meslekî ortamlarda, özellikle Üniversite ve Araştırma Kütüphanecileri Derneği (ÜNAK) Tıp Çalışma Grubunun elektronik tartışma plâtformunda yeni düşünceler üretilmesine vesile olacağını düşünüyoruz.

\section{Kaynakça}

Algermissen, V. (1974). Biomedical librarians in a patient care setting at the University of Missouri-Kansas City School of Medicine. Bulletin of the Medical Library Association, 62(4), 354-358.

Alkan, N. (2002a). Enformasyonistlik mesleği önerisi. Bilgi Dünyası, 3(1),76-92.

Alkan, N. (2002b). Günümüzde tıp ve sağlık bilimleri kütüphaneciliği. F. Rukancı ve diğerleri (yay. haz.). Elektronik Gelişmeler Işığında Araştırma Kütüphaneleri, 24-26 Ekim 2002, Bolu, Bildiriler içinde (s. 17-33). Bolu: Abant İzzet Baysal Üniversitesi.

Alkan, N. (2005). Dizgesel derlemelerin kanıta dayalı tıp uygulamasındaki önemi ve dizgesel derleme üretme sürecinde kütüphanecilerin rolü. M.E. Küçük (yay. haz.). Prof. Dr. Nilüfer Tuncer'e Armağan içinde (s. 42-71). Ankara: Türk Kütüphaneciler Derneği.

Banks, D.E., Shi, R., Timm, D.F., Christopher, K.A., Duggar, D.C., Comegys, M. ve McLarty, J. (2007). Decreased hospital length of stay associated with presentation of cases at morning report with librarian support. Journal of the Medical Library Association, 95(4), 381-387.

Barbour, G.L. ve Young, M.N. (1986). Morning report: Role of the clinical librarian. Journal of the American Medical Association, 255(14), 1921-1922.

Booth, A. ve Brice, A. (2004). Appraising the evidence. A. Booth ve A. Brice (yay.haz.) Evidence-based Practice for Information Professionals: A Handbook içinde (s. 104-118). London, Facet Pub. 
Buchanan, D. (2004). Clinical librarianship. University of British Columbia, School of Library, Archival and Information Studies, Canada. 27 Eylül 2007 tarihinde http://www.slais.ubc.ca/courses/ libr538f/04-05wt2/buchanan.ppt adresinden erişildi.

Cimpl, K. (1985). Clinical medical librarianship: A review of the literature. Bulletin of the Medical Library Association, 73(1), 21-28.

Clevesy, S. R. (1980). A modified clinical librarian program for the community hospital. Bulletin of the Medical Library Association, 68(1), 70-71.

Clinical Informatics Consult Service-CICS. (2008). Clinical information in context: Enabling informed decisions. 2 Ocak 2008 tarihinde http://www.mc.vanderbilt.edu/biolib/services/ cics.html adresinden erişildi.

Davidoff, F. ve Florance, V. (2000). The informationist: A new health profession? Annals of Internal Medicine, 132(12), 996-998.

Demas, J. M. ve Ludwig, L.T. (1991). Clinical medical librarian: The last unicorn? Bulletin of the Medical Library Association, 79(1), 17-27.

Giuse, N.B. (1997). Advancing the practice of clinical medical librarianship. Bulletin of the Medical Library Association, 85(4), 437-438.

Giuse, N.B., Kafantaris, S. R., Miller, M.D., Wilder, K.S., Martin, S. L., Sahte, N.A. ve Campbell, J.D. (1998). Clinical medical librarianship: The Vanderbilt experience. Bulletin of the Medical Library Association, 86(3), 412-416.

Goodall, A.L. (1954). The place of the librarian in the medical team. Bulletin of the Medical Library Association, 42, 19-22.

Hutchinson, S. , Malamud, J., Stearns, N.S. ve Moulton, B. (1981). Preselecting literature for routine delivery to physicians in Community Hospital-based Patient Care Related Reading Program. Bulletin of the Medical Library Association, 69(2): 236-239. 
Jerome, R.N., Giuse, N.B., Gish, K.W., Sahte, N.A. ve Dietrich, M.S. (2001). Information needs of clinical teams: Analysis of questions received by the Clinical Informatics Consult Service. Bulletin of the Medical Library Association, 89(2), 177-184).

Klein, M.S. , Ross, F.V., Adams, D.L. ve Gilbert, C.M. (1994). Effect of online literature searching on length of stay and patient care costs. Academic Medicine, 69(6), 489-495.

Koonce, T.Y., Giuse, D.A., Beauregard, J.M. ve Giuse, N.B. (2007). Toward a more informed patient: Bridging health care information through an interactive communication portal. Journal of the Medical Library Association, 95(1), 77-81.

Lamb, G. (1974). And now clinical librarians on rounds. Journal of the American Medical Association, 230(4), 521.

Lyon, J., Giuse, N.B., Williams, A., Koonce, T.Y. ve Walden, R. (2004). A model for training the new bioinformationist. Journal of the Medical Library Association, 92(2), 188-195.

Marshall, J.G. ve Hamilton, J.D. (1978). The clinical librarian and the patient: Report of a project at McMaster University Medical Centre. Bulletin of the Medical Library Association, 66(4), 420-425.

Medical Library Association-MLA. (2007). History of the association. Oral history project: Voices of the past. Gertrude Lamb. Date of interview: April 5, 1985. 19 Eylül 2007 tarihinde http://www.mlanet.org/about/history/lamb_g.html adresinden erişildi.

Plutchak, T. S. (2000). Informationists and librarians. Bulletin of the Medical Library Association, 88(4), 391-392.

Sargeant, S. J.E. ve Harrison, J. (2004). Clinical librarianship in the UK: temporary trend or permanent profession? Part 1: A review of the role of the clinical librarian. Health Information and Libraries Journal, 21(3), 173-181.

Scherrer, C.S. ve Dorsch, J.L. (1999). The evolving role of the librarian in evidence-based medicine. Bulletin of the Medical Library Association, 87(3), 322-328. 
Sowell, S. L. (1978). LATCH at the Washington Hospital Center, 19671975. Bulletin of the Medical Library Association, 66(2), 218-222.

University of Missouri at Kansas City-UMKC. Health Sciences Library. (2007). Clinical medical librarian program. 2 Ocak 2008 tarihinde http://library.umkc.edu/hsl/about/cmlservices.html adresinden erişildi.

Vanderbilt University Medical Center-VUMC. The Eskind Biomedical Library. (2008). Welcome to the Annette and Irwin Eskind Biomedical Library. 8 Ocak 2008 tarihinde http://www.mc.vanderbilt.edu/biolib/ adresinden erişildi.

Veenstra, R.J. (1992). Clinical medical librarian impact on patient care: A one year analysis. Bulletin of the Medical Library Association, 80(1), 19-22.

Veenstra, R.J. ve Gluck, E.H. (1992). A clinical librarian program in the intensive care unit. Critical Care Medicine, 20(7), 1038-1042.

Wagner, K.C. ve Byrd, G.D. (2004). Evaluating the effectiveness of clinical medical librarian programs: A systematic review of the literature. Journal of the Medical Library Association, 92(1), 14-33.

Williams, M.D., Gish, K.W., Giuse, N.B., Sahte, N.A. ve Carrell, D.L. (2001). The Patient Informatics Consult Service (PICS): An approach for a patient-centered service. Bulletin of the Medical Library Association, 89(2), 185-193.

Winning, M.A. ve Beverley, C.A. (2003). Clinical librarianship: A systematic review of the literature. Health Information and Libraries Journal, 20(Suppl.1), 10-21.

Wolf, D.G., Chastain-Warheit, C.C., Easterby-Gannett, S., Chayes, M.C. ve Long, B.A. (2002). Hospital librarianship in the United States: At the crossroads. Journal of the Medical Library Association, 90(1), 38-48. 